\title{
15- Korona, Korona Virüsü, Kovid-19, Pandemi, Virüs sözcüklerinin tanımı, kökeni ve yazımı
}

\section{Ebubekir ERASLAN ${ }^{1}$}

APA: Eraslan, E. (2021). Korona, Korona Virüsü, Kovid-19, Pandemi, Virüs sözcüklerinin tanımı, kökeni ve yazımı. RumeliDE Dil ve Edebiyat Araştırmaları Dergisi, (25), 231-249. DOI: 10.2900o/rumelide.1036513.

$\ddot{\mathbf{O z}}$

Tüm dünyayı 2020 yılı içerisinde tamamen etkisi altına alan, şu an için altı milyona yakın insanın ölümüne neden olan küresel salgın yüzünden, dünyadaki tüm dillerde olduğu gibi Türkçeye de yepyeni sözcükler, yapılar ve yazımlar gelmiştir. Korona, korona virüsü, kovid-19, pandemi, virüs gibi sözcükler bunlar içerisinde en önde gelenleri olarak neredeyse iki senedir hayatımızın ve de dilimizin içerisinde yaşamaktadır. Dünya genelini etkileyen böyle bir büyük salgının neredeyse bir asırdır görülmemesi, hızlıca tüm dünyaya yayılması, ülkelerin çok hızlı bir şekilde kısıtlamalara gitmek mecburiyetinde kalmaları vb. sebeplerle söz konusu sözcükler konuşulamadan, tartışlamadan dilleri etkiledi ve etkilemeye devam etmektedir. Türkiye'de korona, korona virüsü, kovid 19, pandemi, virüs gibi kelimelere bakıldığında bu sözcüklerin tanımlarının net bir şekilde yapılamadığı, kökenlerine dair farklı farklı görüşlerin olduğu, yazımları konusunda hâlâ bir birlikteliğin sağlanamadığı anlaşılmaktadır. Tüm bunların tespit edilerek bilimsel çıtılarının bir an evvel ortaya çıkarılması, yanlışların doğrulanması, eksikliklerin giderilmesi, doğruların da yaygınlaştırılması gerekmektedir. Bunun için başta Türkiye Cumhuriyeti Sağlık Bakanlığı olmak üzere, Türk Dil Kurumu, Sivil Toplum Kuruluşları, Yazılı ve Görsel Basın ve toplumun tüm kesimlerine düşen büyük sorumluluklar bulunmaktadır. Tüm bu kurum ve kuruluşlarla, fertlerin bağımlı ve bağımsız olarak yapacakları faaliyetlerle daha kalıcı çözümlere ulaşılabileceği gerçeği apaçık bir şekilde ortadadır.

Anahtar kelimeler: Korona, Korona Virüsü, Kovid-19, Pandemi, Virüs

\section{Definition, origin and spelling of the words Corona, Coronavirus, Covid-19, Pandemic, Virus}

\begin{abstract}
Due to the global epidemic, which completely affected the whole world in 2020 and caused the death of nearly six million people, brand new words, structures and spellings came to Turkish as in all languages in the world. Words such as corona, corona virus, covid-19, pandemic, virus have been in our lives and our language for almost two years as the leading ones among these. Such a mojor epidemic affecting the world has not been seen for almost a century, spreading rapidly all over the world, countries have to go to restrictions very quickly, etc. For these reasons, the terms in question have affected and continues to affect languages without being spoken or discussed. When we look at words such as corona, corona virus, covid-19, pandemic, virus in Turkey, it is seen that the definitions of these words cannot be made clearly, there are different opinions about their origins, and there is still no unity in their spelling. It is necessary to determine all of these and put the scientific outcomes
\end{abstract}

Dr. Öğr. Gör., Muğla Sıtkı Koçman Üniversitesi, Türk Dili Bölümü (Muğla, Türkiye), ebubekireraslan@gmail.com, ORCID ID: oooo-0oo3-3713-1242 [Araştırma makalesi, Makale kaylt tarihi: 10.10.2021-kabul tarihi: 20.12.2021; DOI: 10.29000/rumelide.1036513]

RumeliDE Dil ve Edebiyat Araştırmaları Dergisi Osmanağa Mahallesi, Mürver Çiçeği Sokak, No:14/8 Kadıköy - ISTANBUL / TÜRKIYE 34714 e-posta: editor@rumelide.com tel: +90 $5057958124,+902167730616$
Address

RumeliDE Journal of Language and Literature Studies

Osmanağa Mahallesi, Mürver Çiçeği Sokak, No:14/8

Kadıköy - ISTANBUL / TURKEY 34714

e-mail: editor@rumelide.com

phone: +90 5057958124, +90 2167730616 
as soon as possible, to verify the mistakes, to eliminate the deficiencies and to spread the truths. For this, there are great responsibilities falling on the Ministry of Health of the Republic of Turkey, the Turkish Language Institution, Non-Governmental Organizations, the Written and Visual Media and all segments of the society. The fact that more permanent solutions can be achieved with the actions of individuals, dependent and independent, with all these institutions and organizations, stands before us clearly.

Keywords: Corona, Coronavirus, Covid 19, Pandemic, Virus

\section{Giriş}

2019 yılında Çin'de ortaya çıkan daha sonra tüm dünyaya yayılan ve ülkemizde de 2020'nin ilk aylarında görülmeye başlayan küresel salgın nedeniyle tüm dünya dillerinde olduğu gibi Türkçede de korona, korona virüsü, kovid-19, pandemi, virüs gibi sözcükler sıklıkla kullanılmaya başlanmıştır. Üstelik bu sözcükler Türkçeye çok farklı anlamları, yazımları, yapıları ve söyleyişleri de beraberinde getirmiştir. Tüm bu ve buna benzer sözcüklerle yapıları; Türkçe sahaya, halkın kullanımına sokmaktadır. Çünkü dil yaşayan, capcanlı bir varlıktır.

Türkiye; korona, korona virüsü, kovid-19, pandemi, virüs gibi sözcüklerin bazılarılla salgından önce bazılarıyla da tüm dünyada olduğu gibi salgından sonra tanışmıştır. Bugün için korona, korona virüsü, kovid-19, pandemi, virüs sözcükleri terim hâline gelmiş ve toplumun tamamına mal olmuş durumdadır.

Dil, bir milleti oluşturan her bir ferdin ortak malıdır. Küresel bir salgın hâline gelen, hayatları kısıtlayan salgın hastalığa ve onun beraberinde getirdiği sözcüklere karşı başta kamu kurum ve kuruluşları olmak üzere toplumun her bir ferdinin üzerine düşen büyük sorumluluklar bulunmaktadır. T.C. Sağlık Bakanlığı, Türk Dil Kurumu, Yazılı ve Görsel Basın, Sivil Toplum Kuruluşları başta olmak üzere herkesin korona, korona virüsü, kovid-19, pandemi, virüs gibi sözcükleri tanımlarken, yazarken, söylerken üzerlerine büyük sorumluluk düşmektedir. Bu sorumluklar en azından maske-sosyal mesafe-hijyen kadar önemsenmeli ve içselleştirerek hayatın bir parçası hâline getirilmelidir.

\section{Yöntem}

Belgesel tarama yöntemiyle (Karasar, 2009: s. 183) elde edilen bilgilere göre korona, korona virüsü, kovid-19, pandemi, virüs sözcüklerinin tanımı, kökeni ve yazımı yazılı ve elektronik kaynaklara bağlı kalınarak verilmiştir.

Korona, korona virüsü, kovid-19, pandemi, virüs sözcüklerinin yazımı konusunda Türkiye'de en sık kullanılan ve kullanıcıların arama sayılarını gösteren internet arama motorlarından olan "google, instagram, yandex, bing"in 03.04.2021 tarihindeki verilerine; sosyal medya platformu "instagram ve facebook"un 03.04.2021-10.04.2021 tarihleri arasındaki datalarına müracaat edilmiş ve tüm bunlar sayısal verileriyle birlikte tablolar hâlinde sırasıyla ilgili başlıklarda gösterilmiştir. Böylece yazım konusunda hangi sözcük yazımının tercih edilmesiyle daha doğru ve sık kullanıma ulaşlabileceği konusunda ortak bir kanaate varılmaya çalışılmıştır. Ayrıca bu sözcüklerin Yazım Kılavuzu (TDK, 2021) ve Türk dil bilgisi kurallarına göre olması gereken şekilleri hususunda da alan taraması yapılarak durulmuştur.

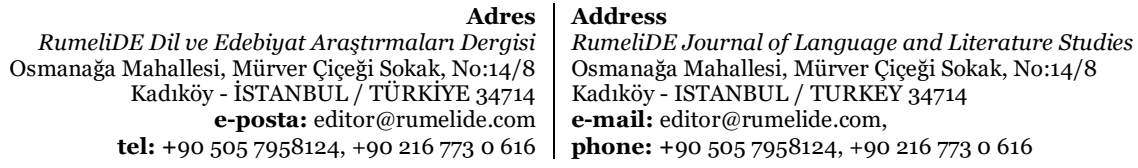
tel: $+905057958124,+902167730616$ 


\section{Amaç}

Çalışmanın amacı; korona, korona virüsü, kovid-19, pandemi ve virüs sözcüklerinin tanımlarını doğru bir şekilde yapmak, kökenlerini tespit etmek, yazımları konusunda ortaya çıkan farklılıkların nedenini belirlemek ve bunları Türkçenin yapısına göre en aza hatta teke indirmek ve de bu sözcüklerin doğru yazımı konusunda literatürün oluşmasına katkıda bulunmaktır. Ayrıca adı geçen sözcüklerin Türkçeleştirilmesi hususunda yapılacak çalışmalara destek olmak hedeflenmiştir.

\section{Korona, Korona Virüsü, Kovid-19, Pandemi, Virüs}

Korona, korona virüsü, kovid-19, pandemi, virüs sözcüklerine bakıldığında kronolojik olarak Türkçede sırasıyla virüs, korona, korona virüsü, pandemi ve kovid-19 sözcüklerinin kullanım alanına çıtığı görülmektedir. Bu sözcüklerden sadece kovid-19 adı, salgından sonra hem dünya dillerine hem de Türkçeye girmiştir. Bunun dışındaki diğer sözcükler, dünyada ve Türkiye'de az da olsa bilinen sözcüklerdir. Günümüzde bu kelimelerin Türkçedeki kullanım sıklıkları diğer yıllara göre daha fazladır. Zaten bu durum, sözcüklerin yazımlarını derlediğimiz arama motorları ve sosyal medya platformlarındaki sayısal verilerden de anlaşılabilmektedir.

\subsection{Korona}

\subsubsection{Tanımı}

Tablo 1. Koronanın tanım bilgileri.

\begin{tabular}{|c|c|}
\hline Güncel Türkçe Sözlük (TDK, 2021) & Güneş tacı \\
\hline $\begin{array}{l}\text { Yabancu Sözlere Karşılıklar Kılavuzu (TDK, } \\
\text { 2021) }\end{array}$ & $\begin{array}{l}\text { Güneş atmosferinin yoğunluğu çok düşük ve çok sıcak } \\
\text { en dış katmanı }\end{array}$ \\
\hline $\begin{array}{l}\text { Türkçe-Ittalyanca Sözlük (Bernardo De Parigi, } \\
\text { haz. Kartallığlu, 2015: s. 537-825) }\end{array}$ & Taç. \\
\hline $\begin{array}{l}\text { Latince Türkçe Sözlük (Kabaağaç ve Alova, 1995: } \\
\text { s. 136) }\end{array}$ & $\begin{array}{l}\text { Çelenk, taç. } \\
\text { İklile takımyıldızı, erafta duran, halka oluşturan } \\
\text { seyirciler. } \\
\text { Bir yeri saran askerler, kuşatma hattı. }\end{array}$ \\
\hline $\begin{array}{l}\text { Su Ürünleri Terimleri Sözlüğ̈̈ (Mustafa } \\
\text { Sarıyyüpoğlu vd, 2009: s. 170) }\end{array}$ & $\begin{array}{l}\text { Deniz lalelerinin tekası. } \\
\text { Rotator gibi bazı hayvanların başlarında bulunan silli, } \\
\text { halkasal yapı. }\end{array}$ \\
\hline $\begin{array}{l}\text { Kimya Terimleri Sözlüğğ (Somer ve Yaşar 2009: } \\
\text { s. 143) }\end{array}$ & $\begin{array}{l}\text { Yüksek gerilimli hatlarda ve kıvılcımla ateşlenen } \\
\text { motorlarda daha çok gözlenen, oksijenin iyonlaşıp } \\
\text { ozon oluşmasına sebep olan elektriksel boşalım etkisi. } \\
\text { Oluşan ozonun şiddetli yükseltgeyici etkisinden dolayı } \\
\text { bu tür yerlerdeki kablo, tel veya fiş bağlantılarında } \\
\text { yükseltgenmeye dirençli naylon, neopren ve diğer } \\
\text { sentetik maddeler kaplama için kullanılır. }\end{array}$ \\
\hline $\begin{array}{l}\text { Biyoloji Terimleri Sözlüğg̈ü (Karol vd, 2010: s. } \\
\text { 383) }\end{array}$ & $\begin{array}{l}\text { Aken tipi meyveye sahip bazı bitki meyvelerinin } \\
\text { üzerinde taç şeklinde yer alan yapılar. } \\
\text { Deniz lalelerinin tekası. } \\
\text { Rotatar gibi bazı hayvanların ön tarafında bulunan } \\
\text { silli, halkasal yapı. }\end{array}$ \\
\hline $\begin{array}{l}\text { Latince Tıp Terimleri Sözlü̈̆̆̈̈ (Güler, 2012: s. } \\
466)\end{array}$ & $\begin{array}{l}\text { Taç, baş çelengi, tesbihcik çiçekte taç; taç biçimindeki } \\
\text { yapı; taç benzeri kıvrım yapmış oluşum; dişin } \\
\text { dişetlerinin dışında kalan bölümü. }\end{array}$ \\
\hline $\begin{array}{r}\text { Adres } \\
\text { RumeliDE Dil ve Edebiyat Arasstrmalar Dergisi } \\
\text { Osmanağa Mahallesi, Mürver Ciçeği Sokak, No:14/8 } \\
\text { Kadıköy - İSTANBUL / TÜRKIYE } 34714 \\
\text { e-posta: editor@rumelide.com } \\
\text { tel: }+90 \text { 505 7958124, +90 } 216773 \text { o } 616\end{array}$ & $\begin{array}{l}\text { Address } \\
\text { RumeliDE Journal of Language and Literature Studies } \\
\text { Osmanağa Mahallesi, Mürver Cicceği Sokak, No:14/8 } \\
\text { Kadiköy - ISTANBUL / TURKEY } 34714 \\
\text { e-mail: editor@ @rumelide.com, } \\
\text { phone: +90 505 7958124, +90 } 216773 \text { o } 616\end{array}$ \\
\hline
\end{tabular}




\begin{tabular}{|l|l|}
\hline $\begin{array}{l}\text { Veteriner Hekimliği Terimleri Sözlüğ̆̈̈ } \\
\text { (Veteriner Hekimliği Terimleri Sözlüğü Çalışma } \\
\text { Grubu, 2017: s. 1207) }\end{array}$ & $\begin{array}{l}\text { Taç, çelenk. } \\
\text { Taç veya çelenge benzeyen oluşum. }\end{array}$ \\
\hline Zülfikar (2020c: s. 11) & Taç; ay halesi, ay ağıll. \\
\hline
\end{tabular}

Derleme Sözlüğ̈̈’nde (2021) korona kelimesinin, Maçka ve köyleri-Trabzon'da zavall karşıllğıyla tespit edildiği görülmektedir. Mevcut bu durumun eş seslilikten kaynaklandığı düşünülebilir. Ayrıca Osmanlıcadan Türkçeye Söz Karşıllkları Tarama Dergisinnde (1934: s. 155) korana koran sözcüğünün, bedbahtlık karşllğıyla Trabzon'dan derlendiği bilgisi de yer almaktadır.

Korona sözcüğü; Kimya Terimleri Sözlüğ̈̈’nde (Somer ve Yaşar, 2009: s. 143), Su Ürünleri Terimleri Sözlüğü’nde (Mustafa Sarıeyyüpoğlu vd, 2009: s. 170), Veteriner Hekimliği Terimleri Sözlüğü’nde (Veteriner Hekimliği Terimleri Sözlü̆̆̈ü Çalışma Grubu, 2017: s. 188, 403, 886, 1207, 1215, 1309, 1364, 1833, 1897, 1942, 1970, 2056, 2062, 2120) birer kez geçmektedir. Açılamalı Yürek Bilimi Terimleri Sözlüğü’nde (Acartürk, 2020: s. 134-139) iki kez koronal düzlem ve Latince Tip Terimleri Sözlüğü’nde (Güler, 2012, s. 92) coronalis, coronans, coronare, coronatus, coronarius madde başları ve ciliary corona, corona capitis, corona ciliaris, corona clinica, corona dentis, coron glandis, corona glandis penis, corona radiata, corona seborrheica, corona veneris iç maddeleriyle geçmektedir. Tümünün toplamindaysa yirmi bir koronalı sözcügün; arterya koronarya dekstra, arterya koronarya sinistra, coronaviridae, hindilerin koronavirüs enteritisi, korona, korona dentis, korona radiata, koronalis, koronaryus, koronavirüsler, koryum korona, ligamentum koronaryum hepatis, margo koronalis, regio koronalis, SARS'la ilişkili koronavirüs, sığırlarm koronavirüs enfeksiyonu, sinüs koronaryus, sulkus koronalis, sulkus koronaryus, sutura koronalis, tela subkutenea korona terimleriyle veya bu sözcüğün türevleriyle kullanıldığı görülmektedir. Özellikle covid-19 virüsünün orijinin hayvan kaynaklı olduğu düşünülürse Veteriner Terimleri Sözlüğ̈̈’ndeki (2017: s. 188, 403, 886, 1207, 1215, 1309, 1364, 1833, 1897, 1942, 1970, 2056, 2062, 2120) yirmi bir terimin varlığının nedeni daha iyi anlaşılmaktadır. Zira literatür, korona öncesinde de korona sözcügüne ve onun türevlerine yabancı değildi ve korona terim olarak literatürde kullanılan bir sözcüktü.

Netice itibarıyla kovid-19'a neden olan virüsün yüzeyinde bulunan ve uzmanların mikroskobik incelemeleri neticesinde bir taca (korona) benzettikleri küçük sivri uçlar korona olarak adlandırılmış, bu sözcüğün virüs kelimesiyle de birleşmesiyle salgına neden olan virüsün adı konulmuştur. Hatta korona adlandırması hastalığın kovid-19 gibi kısaltılmış adı hâline dahi gelmiştir.

Mevcut tanımlar dikkate alındığında koronanın su ürünleri, kimya, biyoloji, tıp, veterinerlik, kimya, gök bilimi alanlarında benzer/farklı tanımlarının yapıldığı görülmektedir. Bu sebeple; tıp literatüründeki kullanım alanının benzetme ilgisiyle sağlandığı düşünüldüğünde korona sözcüğünün Türkçe karşılığının taç sözcüğüne denk gelmesi gerektiği anlaşılmaktadır.

\subsubsection{Kökeni}

Tablo 2. Koronanın köken bilgileri.

\begin{tabular}{|l|l|}
\hline Güncel Türkçe Sözlük (TDK, 2021) & İtalyanca \\
\hline Su Ürünleri Terimleri Sözlüğ̈̈ü (Mustafa Sarıyyüpoğlu vd, 2009: s. 170) & Latince \\
\hline Kimya Terimleri Sözlüğ̈̈ (Somer ve Yaşar, 2009: s. 143) & İngilizce \\
\hline
\end{tabular}

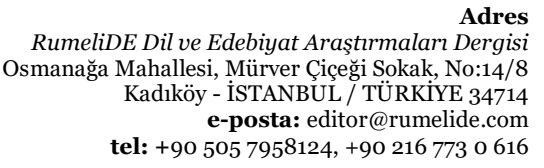

Adres
RumeliDE Dil ve Edebiyat Araşturmaları Dergisi tel: +90 505 7958124, +90 2167730616
Address

RumeliDE Journal of Language and Literature Studies

Osmanağa Mahallesi, Mürver Çiçeği Sokak, No:14/8

Kadıköy - ISTANBUL / TURKEY 34714

e-mail: editor@rumelide.com,

phone: +90 5057958124, +90 2167730616 
Yukarıdaki basılı ve elektronik sözlükler koronanın kökenine dair farklı görüşleri barındırsa da sözcüğün aslının corona olduğu ve Latinceden (Mustafa Sarıyyüpoğlu vd, 2009: s. 170) İtalyancaya (Güncel Türkçe Sözlük, 2021; Bernardo De Parigi, Türkçe-İtalyanca Sözlük, haz. Kartallığlu, 2015: s. 158), İtalyancadan da İngilizceye (Somer ve Yaşar, 2009: s. 143) geçtiği, oradan da tüm dünya dillerine ödünçleme yapıldığı anlaşılmaktadır. Yani sözcüğün Latinceden sonraki kaynak dili İngilizce olmuş, buradan da tüm dünya dillerine yayılmıştır.

\subsubsection{Yazımı}

1665 yllında Bernardo De Parigi'nin yazdığı Türkçe-İtalyanca Sözlük’te (Kartallığlu, 2015: s. 537-825) korona, corona şeklinde yazılmıştır. Veteriner Hekimliği Terimleri Sözlüğü’nde (Veteriner Hekimliği Terimleri Sözlüğü Çalışma Grubu, 2017: s. 1207) de koronanın kaynak dilde corona şeklinde yazıldığı belirtilmektedir.

Yazım Kılavuzu'nda (TDK, 2021) “Alıntı Kelimelerin Yazılışı” bölümünde dört başlık bulunmaktadır. Bu dört başlığın hemen altında da iki alt başlık yer almaktadır. Bu iki alt başlık bu bölümün aynı zamanda istisnaî bilgilerini de içermektedir. Burada korona sözcüğüyle ilgili doğrudan olmasa da dolaylı olabilecek şu iki istisnaî bilgi bulunmaktadır:

Aşağıdaki durumlarda Batı kökenli kelimeler özgün biçimleri ile yazılırlar:

1. Bilim, sanat ve uzmanlı dallarında kullanılan bazı terimler: andante (müzik), cuprus (kimya), deseptly (eczacllk), quercus, terminus technicus (teknik terim) $v b$.

2. Latin yazı sistemini kullanan dillerden alınma deyim ve sözler: Veni, vidi, vici (Geldim, gördüm, yendim); conditio sine qua non (Olmazsa olmaz); eppur si mouve (Dünya her şeye rağmen dönüyor); to be or not to be (olmak veya olmamak); l'art pour l'art (Sanat sanat içindir); l'Etat c'est moi (Devlet benim); traduttore traditore (Çevirmen haindir); persona non grata (istenmeyen kişi) $v b$.

Söz konusu istisnaî durumların, ödünçleme yoluyla Türkçeye geçmiş kelimelerin orijinal yazılış ve söyleyişinden kopmamak adına konulduğu açıktır. Fakat net bir kuralın ortaya konulmaması, ilk istisnadaki “bazı” gibi bir ifadeyle bilimsellikten uzaklaşılması kafa karışıklığını artırmaktadır.

Tablo 3. Koronanın farklı yazımlarının internet arama motorlarındaki sonuçları.

\begin{tabular}{|l|l|l|l|}
\hline \multicolumn{2}{|c|}{ Google } & Yandex & Bing \\
\hline corona & 913.000 .000 & 10.000 .000 & 68.000 .000 \\
\hline korona & 192.000 .000 & 20.000 .000 & 28.200 .000 \\
\hline
\end{tabular}

Tablo 4. Koronanın farklı yazımlarının sosyal medya platformlarındaki sonuçları.

\begin{tabular}{|l|l|l|}
\hline \multicolumn{2}{|c|}{ İnstagram } & Facebook \\
\hline corona & 28.400 .000 & 3.300 .000 \\
\hline korona & 1.600 .000 & 160.000 \\
\hline
\end{tabular}

Yukarıdaki tablolarda hem internet arama motorlarında hem de sosyal medya platformlarında coronalı yazımın korona lı yazıma göre daha sık tercih edildiği görülmektedir. Bunda da sözcüğün kaynak dilinin Batı kökenli olması ve dünyada bu isimle adlandırılması nedeniyle ve de evrensellik düşüncesiyle coronalı şeklin en azından sağlık bilimlerinde tercih edilmek istenmesinden kaynaklandığı

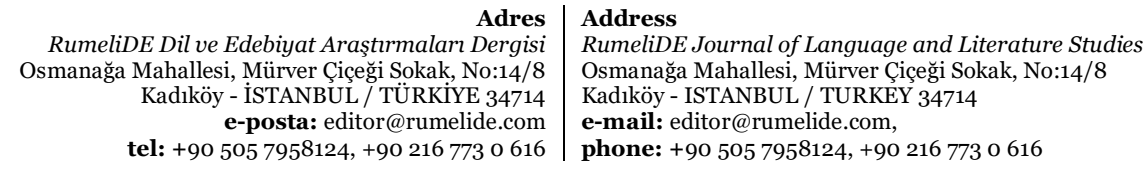


düşünülmektedir. Bunlara rağmen corona veya korona sözcüğünün aynı etiket bilgisinde yer aldığı örneklere de tanıklık edilmektedir. (bkz. Covid-19 Sözlüğü, 2021)

Türkçede tabiat taklidi sözcüklerin dışında kelime başında genellikle $c$ sesinin bulunmayışı (Ergin, 2007: s. 59); Batı dillerinden alıntılanan ve başında $c$ ünsüzü bulunan sözcüklerin tonsuz hâllerinin tercih edilmesi ve bunun örneğinin yabancı kökenli kelimelerde rastlanması (Özkan, Tören ve Esin, 2006: s. 347); sözcüğ̈̈n orijinalinin $c$ harfiyle yazılıp Türkçede $k$ harfiyle okunması, tam olarak doğru olmasa da Türkçenin konuşulduğu gibi yazıldığı fikri gibi sebeplerle coronanın korona şeklinde yazılmasını ve okunmasını zarurî hâle getirmektedir.

\subsection{Korona Virüsü}

\subsubsection{Tanımı}

Tablo 6. Korona virüsünün tanım bilgileri.

\begin{tabular}{|c|c|}
\hline Covid-19 Sözlüğ̈̈̈ (T.C. Sağlık Bakanlı̆̆ı, 2021) & $\begin{array}{l}\text { Tek zincirli RNA'ya sahip, zarflı, yüzeyinde protein } \\
\text { çııntıları olan büyük virüs ailesi. } \\
\text { Koronavirüsler (CoV), hafif ve orta derecede şiddetli } \\
\text { solunum yolu hastalıkların yanı sıra MERS (Orta } \\
\text { Doğu Solunum Sendromu), SARS (Şiddetli Akut } \\
\text { Solunum Sendromu) ve COVID-19 (Yeni Koronavirüs } \\
\text { Hastalı̆̆ı) gibi şiddetli seyreden hastalıklardan da } \\
\text { sorumludur. }\end{array}$ \\
\hline $\begin{array}{l}\text { Biyoloji Terimleri Sözlüğg̈ü (Karol vd, 2010: s. } \\
\text { 125) }\end{array}$ & $\begin{array}{l}\text { Soğuk algınlığı ve üst solunum yolu enfeksiyonlarına } \\
\text { sebep olan, 80-160 nm. çapında tek iplikli RNA } \\
\text { (pozitif iplikli) içeren kılıflı, kılıfın üzeri çıkıntılarla } \\
\text { kaplı virüs familyası. }\end{array}$ \\
\hline $\begin{array}{l}\text { Veteriner Hekimliği Terimleri Sözlüğği } \\
\text { (Veteriner Hekimliği Terimleri Sözlüğü Çalışma } \\
\text { Grubu, 2017: s. 1207) }\end{array}$ & $\begin{array}{l}\text { RNA genom yapısına sahip, yaklaşılk } 100 \mathrm{~nm} \text { çapında, } \\
\text { zarflı ve güneş hüzmesi görünümünde köpek, kedi, } \\
\text { sığır ve insan başta olmak üzere birçok türde özellikle } \\
\text { mide-bağırsaklarda enfeksiyonlara neden olan virüs } \\
\text { ailesi. Coronaviridae }\end{array}$ \\
\hline
\end{tabular}

Korona virüsü; Veteriner Hekimliği Terimleri Sözlüğü’nde (Veteriner Hekimliği Terimleri Sözlüğü Çalışma Grubu, 2017: s. 886-1207-1897-1942) birer kez olmak üzere dört defa hindilerin koronavirüs entarisi, koronavirüsler, SARS'la ilişkili koronavirüs, sığırların koronavirüs enfeksiyonu terimleriyle kullanılmaktadır. Korona virüsü hastalığının Çin'de hayvandan insana bulaşması sonucu başladığı akla getirilir ve Veteriner Terimleri Sözlüğ̈̈’ndeki (2017: s. 886-1207-1897-1942) dört terimin varlığı da bu bilgiye eklenirse bilim dünyasının korona virüsü adına yabancı olmadığı anlaşılmaktadır. Belki de bu yüzden yeni tip korona virüsü teriminin, alan yazınında korona virüsü yerine zaman zaman tercih edilerek neden kullanıldığı daha iyi anlaşılmaktadır.

Yukarıdaki tanımlara dayanarak koronanın taç, virüsün de zehir anlamına geldiği düşünülürse korona virüsü için taç zehri veyahut virüsün artık Türkçeleştiği varsayılırsa taç virüsü karşılığı kullanılabilir.

\subsubsection{Kökeni}

Tablo 7. Korona virüsünün köken bilgisi.

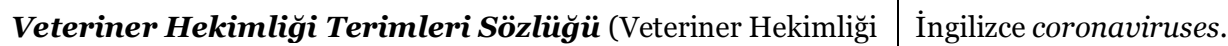
Terimleri Sözlüğü Çalışma Grubu, 2017: s. 1207)

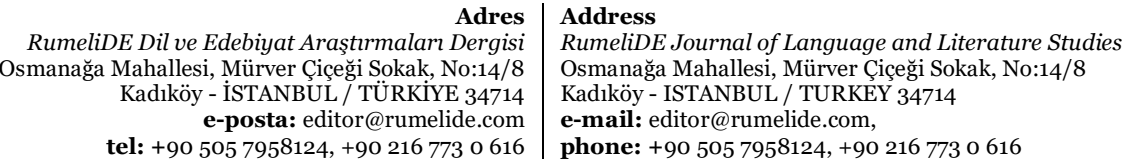


Yukarıdaki köken bilgisi, korona virüsün tüm dünyaya yayıldığı kaynak dilin düşünülerek verildiği açıktır. Zira yukarıda korona maddesinde belirtildiği üzere bu sözcügün kökeni Latincedir. Korona Latinceden İtalyancaya, oradan İngilizceye ve oradan da tüm dünya dillerine geçmiştir. Benzer durum virüs için de geçerlidir. Virüs de Latince virusten İngilizceye, oradan da diğer dillere ödünçlenmiştir.

Özetlemek gerekirse korona virüsü, korona ve virüs sözcüklerinden oluşmuş bir birleşik sözcüktür. Koronanın Latince coronadan, virüsün de Latince virus sözcü̆üünden alıntılandığı düşünüldüğünde ortaya köken olarak Latince iki sözcükten oluşmuş bir birleşik sözcük çlkmaktadır. Tabii ki korona virüsünü popüler hâle getiren, onu diğer dillere transfer eden dil İngilizcedir. Bu yüzden sözlüklerde korona virüsü kelimesinin kökeninin İngilizce olduğunun yazılması tamamen doğru değildir demek de doğru değildir.

\subsubsection{Yazımı}

Korona ve virüs sözcüklerinin birleşmesinden oluşmuş korona virüsü Türkçede artık bir terim olarak kullanılan, ayrı yazılan ve de ayrı yazılması gereken bir birleşik kelimedir.

Birleşik kelime; "yeni bir kavramı veya yeni bir nesneyi karşılamak üzere iki ya da daha çok kelimenin belirli şekil bilgisi kurallarına uyularak bir anlam birliği oluşturacak biçimde bir araya getirilmesidir" (Korkmaz, 2017b: s. 190) veyahut "bir kavram ya da nesneyi karşlamak amacıyla, anlam değerlerini yitiren iki veya daha çok sözün birleştirilmesi ile oluşturulan yeni sözlerdir” (Karaağaç, 2013: s. 207). Demek ki birleşik sözcük; yeni bir kavramı karşılamak için birden fazla sözcüğün belirli şekil ve anlam kurallarına uyup bir araya getirilmeleriyle oluşturdukları yeni sözlerdir. Buna göre coronanın sözcük başında tonsuzlaşması, virusün de dudak uyumuna girmesi ve iki sözcüğün birleşmesi esnasında oluşan belirsiz isim tamlasına iyelik ekinin de eklenmesiyle oluşturulan korona virüsü sözcügü; Türkçe ad + ad+(s)I yapım kuralına göre meydana getirilerek birleştirilmiş.

Terim; "bilim, teknik, sanat, spor, zanaat gibi çeşitli uzmanlık alanlarının kavramlarına verilen sınırlı ve özel anlamdaki ad" (Korkmaz, 2017b: s. 213) veyahut "bilim, teknik, sanat, spor zanaat gibi çeşitli uğraşı alanlarının kavramlarına verilen sınırlı ve özel biçim ve de anlamları ifade eder" (Karaağaç, 2013: s. 798). O zaman terim; farklı uzmanlık alanlarında bir kavramı karşılamak amacıyla kullanılan sınırl,, özel biçimli ve anlamlı sözlerdir. Buna göre korona virüsünün tıp literatüründe kullanılması sınırını, birleşik yapıda ve ayrı yazılması biçimini, korona ve virüsün birleşmesiyle yeni bir olguyu ifade etmesi de anlamını belirlediğinden korona virüsü artık bir tıp terimi hâline gelmiştir. Ayrıca korona virüsünün; 2019 yllında başlayan ve tüm dünyaya yayılan bir virüsün ana kaynağı olması, insanlığı her alanda etkilemesi, onu sadece tıp literatürünün içinde sınırlandırmanın doğru olmadığını da akla getirtmektedir.

Terimler; "ihtiyaç duyuldukça yapılan, türetilen kelimelerdir" (Zülfikar, 1991a: s. 164). Bu terimler zaman zaman basit, zaman zaman türemiş, zaman zaman da birleştirme yoluyla türetilen sözcüklerdir. Bunlardan iki sözcügün birleştirilmesiyle oluşturulan terimler, ancak tek bir sözcüğün söz konusu kavramı tek başına karşılayamayacağı zaman kullanılan bir yöntem olmalıdır. Birleştirme yönteminin Türkçede sözcük türetmede üretken olması ve sık kullanılması (Çürük, 2017: s. 6), bu yönteme çok fazla başvurulmasına neden olmaktadır. Korona virüsü sözcüğü de, iki ayrı sözcüğün genellikle tamlama ile bir araya getirilerek birleştirme [ $\mathrm{ad}+\mathrm{ad}+(\mathrm{s}) \mathrm{I}]$ yöntemiyle (Eker, 2013: s. 314-322) oluşturulduğu böyle bir terimdir.

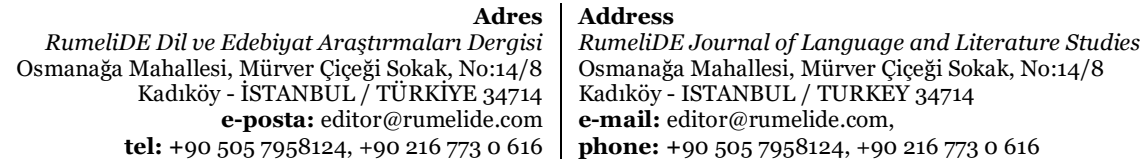


Terim türetmek yabancı dilden bir sözü birebir tercüme etmek demek değildir. Onu Türkçe olarak kısa ve en kapsamlı biçimde ifade edebilmektir. Fakat mecbur kalındığında Doğu ve Batı kökenli kelime köklerinden de yararlanılabilmekte (Zülfikar, 1991a: s. 156) ve bu sözler birleştirilebilmektedir. Birleştirme yoluyla sürekli olarak yeni kelimelerin kullanılması, yazılış güçlüklerini bir kat daha artırmakla kalmamakta, kapsamlı bir kural getirilmesini de engellemektedir (Zülfikar, 1991a: s. 156). Söz gelimi Yazım Kılavuzu (TDK, 2021) birleşik kelimelerin ayrı ya da birleşik yazılışıyla ilgili şu kuralı koymaktadır:

\section{Birleşik Kelimelerin Yazılışı}

\begin{tabular}{|l|l|}
\hline A. Bitişik Yazılan Birleşik Kelimeler & B. Ayrı Yazılan Birleşik Kelimeler \\
\hline $\begin{array}{l}\text { 3. Madde : Kelimelerden her ikisi veya ikincisi, } \\
\text { birleşme sırasında anlam değişmesine uğradığında bu } \\
\text { tür birleşik kelimeler bitişik yazılır. }\end{array}$ & $\begin{array}{l}\text { 2. Madde : Birleşme sırasında kelimelerden hiçbiri } \\
\text { veya ikinci kelimesi anlam değişikliğine uğramayan } \\
\text { birleşik kelimeler ayrı yazılır. }\end{array}$ \\
\hline
\end{tabular}

Görüldüğü üzere her iki kural bilgisinin de uzlaştığı nokta birleşik sözcüğü oluşturan her iki sözcügün veya ikinci sözcüğün anlam değişmesine uğrayıp uğramadığıdır. Yani ilk kelimenin kendi anlamında olmaması TDK tarafından bir sözcüğün ayrı yazılması için sebep teşkil etmemektedir. Konan kurala göre birleşik yazmak için ikinci kelimenin kendi anlamının dışına çıkması gerekmektedir. O zaman sondan başa doğru gelip tamlanandaki virüs sözcüğü incelenirse virüsün herhangi bir anlam değişikliğine uğramadığına şahitlik edilmektedir. Tanımlara göre ilk sözcüğe bakmaya gerek olmasa da, taç anlamına gelen korona sözcüğünün virüsün mikroskop altındaki görüntüsünün taca benzemesi üzerine verildiği bilinmektedir. Demek ki ilk sözcükte bir benzetme ilgisi vardır. Fakat tanımlarda birleşik kelimenin ikincisinin anlam değişikliğine uğrayıp uğramadığına bakılmış, ilk sözcükteki benzetme veya iki sözcüğün oluşturduğu sıfat tamlamasına bakılmamış (Zülfikar, 2015b: s. 318) veyahut da bu durum dikkate alınmamıştır. Dolayısıyla benzetme unsuru, TDK tarafından sözcükleri birleşik yazmak için bir ölçüt olarak görülmediğinden korona virüsü birleşik yazılmamalıdır.

Korona virüsü sözcügünün yazımında dikkat edilmesi gereken diğer bir faktör de tamlanandaki iyelik ekinin zaman zaman düşürülerek yazılmaması ve söylenmemesidir. Esas kaynak dili Latince olan korona ve virüs sözcükleri bir araya geldiği zaman ortaya bir birleşik sözcük çıkmaktadır. Terim hâline de gelen bu sözcükteki olması gereken ve zaman zaman söylenmeyip yazılmayan tek Türkçe unsur tamlanandaki üçüncü tekil kişi iyelik [ +(s)I ] ekidir. Çünkü Türkçe isim tamlamalarında tamlanan mutlaka iyelik eki alır (Yelten, 2010: s. 271) ve Türkçedeki iyelik ekleri, eklendiği kelimeye hem sahiplik hem mülkiyet hem de kişi kavramı kazandırmaya yarayan eklerdir (Parlatır, Şahin, 2011: s. 47). Ayrıca belirsiz isim tamlamalarında tamlayan ile tamlanan arasındaki ilgi kalıcı olduğundan belirsiz isim tamlamaları bir nesnenin adı olmaya, tür adı olmaya da elverişlidir (Özkan vd., 2006: s. 569). Bu yüzden korona ve virüs isimlerinin bir araya gelerek oluşturduğu bu birleşik teriminin (korona virüsü) iyelik ekiyle birlikte yazılması ve söylenmesi gerekmektedir. Ayrıca yabancı köklere dayanan ve birleşik yazılagelen kelimelere karşılık aranırken birleşik yazma etkisinden kurtulunmalı; bu sözcüklerin Türkçe yazımları konusunda kaynak dile göre değil hedef dile göre hareket edilmeli, yeni terimlerde sebepsiz kelime birleştirilmesine gidilmemeli, özellikle belirtisiz isim tamlaması biçiminde bulunan kelimeler birleşik yazılmamalıdır (Zülfikar, 1991a: s. 155-166). İşte tüm bu sebeplerle kaynak dildeki coronavirusün Türkçe kullanımının ayrı olarak yazılması ve korona virüsünün de ayrı yazılan birleşik ad kategorisinde incelenmesi arz etmektedir.

Özetle Türkçe; coronavirus sözcüğünü Türkçeleştirmek için önce virüs kelimesinin son hecesindeki ünlüyü kalınlık-incelik uyumuna sokmuş, daha sonra sözcük başındaki ünsüzü tonsuz şekle geçirmiş,

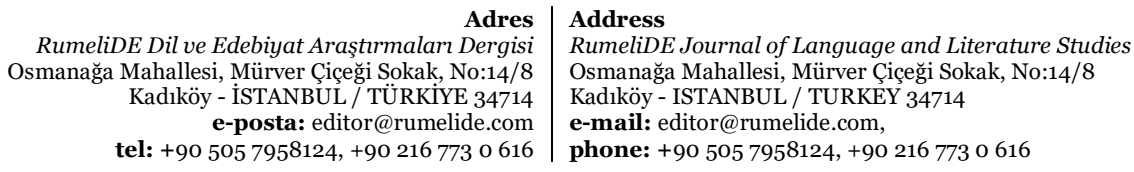


belirsiz isim tamlamasının gereği olarak da sonuna +(s)I üçüncü tekil kişi iyelik ekini ekledikten sonra sözcügü terimleştirerek birleşik sözcük grubuna dâhil edip ayrı bir şekilde yazmıştır.

Tablo 8. Korona virüsünün farklı yazımlarının internet arama motorlarındaki sonuçları.

\begin{tabular}{|l|l|l|l|}
\hline \multicolumn{2}{|c|}{ Google } & Yandex & Bing \\
\hline corona virus & 3.210 .000 .000 & 3.000 .000 & -2 \\
\hline coronavirus & 1.990 .000 .000 & 10.000 .000 & - \\
\hline corona virüs & 1.090 .000 .000 & 1.000 .000 & 1.680 .000 \\
\hline corona virüsü & 32.400 .000 & 1.000 .000 & 993.000 \\
\hline coronavirüs & 2.070 .000 .000 & 153.000 & 272.000 \\
\hline coronavirüsü & 337.000 & 1.000 .000 & 102.000 \\
\hline korona virüs & 127.000 .000 & 466.000 & 151.000 .000 \\
\hline korona virüsü & 46.900 .000 & 464.000 & 998.000 \\
\hline koronavirüs & 367.000 .000 & 2.000 .000 & 2.260 .000 \\
\hline koronavirüsü & 13.500 .000 & 3.000 .000 & 189.000 \\
\hline
\end{tabular}

Tablo 9. Korona virüsünün farklı yazımlarının sosyal medya platformlarındaki sonuçları.

\begin{tabular}{|l|l|l|}
\hline \multicolumn{2}{|c|}{ İnstagram } & Facebook \\
\hline corona virus & -3 & - \\
\hline coronavirus & 3.500 .000 & 6.000 .000 \\
\hline corona virüs & - & - \\
\hline corona virüsü & - & - \\
\hline coronavirüs & - & 25.000 \\
\hline coronavirüsü & 761.000 & 27.000 \\
\hline korona virüs & - & - \\
\hline korona virüsü & - & - \\
\hline koronavirüs & 844.500 & 45.000 \\
\hline koronavirüsü & 616.700 & 21.000 \\
\hline
\end{tabular}

Yukarıdaki tablolardan ve verilerden de anlaşılacağı üzere korona virüsü sözcüğünün on farklı yazım çeşidi üstteki mecralarda yer almaktadır. Bunlar içerisinde Türkçe açısından en uygun ve doğru olanı korona virüsü terimi ve bunun ayrı yazılış şeklidir. Buna rağmen Türkiye'de farklı yazımların aynı kurum içerisinde dahi olsa varlığı görülebilmektedir. (bkz. Covid19.saglik.gov.tr)

\footnotetext{
${ }^{2}$ Bing üzerinden corona virus ve coronavirus sözcükleri için sayısal verilere ulaşlamamıștır.

3 İnstagram ve facebook gibi mecralarda birleșik yazılmayan etiketlere yer verilmediği için tabloda ayrı yazılan sözcüklerle ilgili sayısal verilere ulaşılamamıştır. Bu durum diğer örneklerde de tek tek - işaretiyle gösterilmiş fakat dipnotta tek tek belirtilmemiştir ve belirtilmeyecektir.

Adres

RumeliDE Dil ve Edebiyat Araştırmaları Dergisi Osmanağa Mahallesi, Mürver Çiçeği Sokak, No:14/8 Kadıköy - ISTANBUL / TÜRKIYE 34714 e-posta: editor@rumelide.com tel: +90 $5057958124,+902167730616$

Address

RumeliDE Journal of Language and Literature Studies

Osmanağa Mahallesi, Mürver Çiçeği Sokak, No:14/8

Kadıköy - ISTANBUL / TURKEY 34714

e-mail: editor@rumelide.com

phone: +90 505 7958124, +90 2167730616
} 


\subsection{Kovid-19}

\subsubsection{Tanımı}

Tablo 11. Kovid-19'un tanım bilgisi.

\begin{tabular}{|l|l|}
\hline Covid-19 Sözlü ğ̈̈ & İlk olarak Çin’in Vuhan şehrinde 2019 yılı Aralık ayının sonlarında ortaya \\
(T.C. Sağlı Bakanlığı, 2021) & çıan bulaştığı kişilerde ateş, öksürük, nefes darlığı gibi belirtilere neden \\
& olan hastalı; yeni koronavirüs hastalığı. \\
& Açıklama: COVID-19’a neden olan virüsün adı SARS-CoV-2'dir.
\end{tabular}

Tanımda da görüldüğü üzere kovid-19 aslında bir yeni tip korona virüsü hastalı̆̆ıdır. Bu yüzden kovid19’un Türkçe olarak tanımlanması gerekirse yeni taç virüsü ya da kaynak dildeki birleştirilmiş sözcüklerinden hareket edilirse taç virüsü hastalı̆̆ı-2019 denilebilir.

Dünya Sağlık Örgütü (DSÖ) 2020 ylının şubat ayında yaptığı açıklamayla tüm dünyayı etkilemeye başlayan hastalığın adını Coronavirüs Disease 2019'un kısaltılmış hâliyle Covid-19 olduğunu, bu hastalı̆̆a neden olan virüsünse Severe Acute Respiratory Syndrome Coronavirus 2'nin kısa şekliyle SARS-CoV-2 olduğunu bildirmiştir.

Hastalığa sebep olan SARS-CoV-2 virüsünün adı Türkçede pek yaygınlaşmasa da hastalığın adı olan kovid-19 artık dilimize pelesenk olmuştur. Sözcük zaten artık literatüre girdiği için de terimleşmiştir.

\subsubsection{Kökeni}

Gelişen, değişen dünya ve teknoloji, yeni sözcüklere olan ihtiyacı arttırmaktadır. Bu sebeple yeni sözcükler türetilmekte ve türetilmeye de devam etmektedir. Sözcük yapımı/türetimi bir süreçtir. $\mathrm{Bu}$ süreçte yeni sözcük ortaya koymak için çeşitli sözcük üretme yöntemleri de kullanılmaktadır. (Çürük, 2017: s. 4) İki sözcüğün hecelerinin ya da parçalarının bir araya getirilmesiyle oluşturulan yeni sözcük türetim yollarından birisi de karma yöntemdir (Eker, 2013: s. 314-322). Kovid-19 da Coronavirüs Disease 2019 birleşik isminden co-, vi- heceleri ve d harfinin birleştirilmesi, sona da 19 sayısının eklenmesiyle karma şekilde oluşturulmuş bir birleşik sözcüktür.

Kovid-19 birleşik sözcüğünün oluşturulmasında hece, harf ve rakamdan oluşan birden fazla unsur dâhil edildiği için bu yeni sözcük türetme şekline karma yöntem denilmiştir. Diğer dünya dillerinde olduğu gibi Türkçede de tercih edilen bu karma sözcük türetme yöntemi; bilinçli ve istendik bir çabanın sonucunda ortaya çıkmaktadır (Paylan, 2015: s. 166). Özellikle karma yöntemle oluşturulan sözcük türetme yollarının son yıllarda Türkiye'de de sıklıkla görüldüğüne (bkz. Şenel, 2009: s. 99-109; Üstünova vd. 2009: s. 395-411) tanıklık edilmektedir.

Korona ve virüs sözcüklerinin Latinceden ödünçlendiği yukarıda söylenmişti. Coronavirüs Disease 2019'daki "disease" sözcüğündeki “-dis” Latince ön ektir, "ease” sözcügü de köken olarak Fransızcadır (Chambers, 1874: s. 130-146). Hastalığın adının yanına kısa çizgiyle eklenen rakamın da bu hastalığın ortaya çıktığı yllı ifade ettiği anlaşılmaktadır. Dolayısıyla kovid-19; köken olarak Latince-Fransızca sözcüklerin birinci veya ilk iki harfinin karma yöntemle birleştirilerek kısaltmalı bir şekilde söylendiği bir birleşik isim hâline gelmiş ve artık terimleşmiştir. Fakat kovid-19 sözcüğü de İngilizce aracıllğıyla dünya dillerine ihracat edilmiştir.

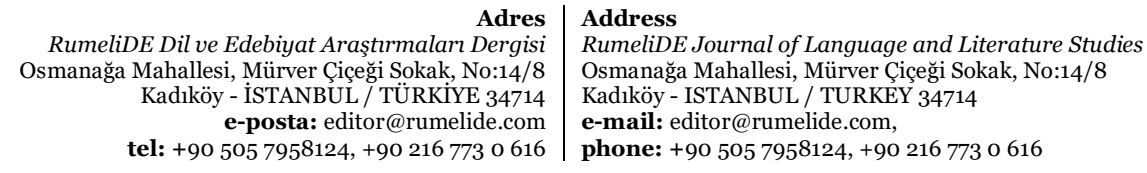


Tablo 12. Kovid-19’un köken bilgisi.

\begin{tabular}{|l|l|}
\hline Kovid-19 & Latince-Fransizca (İngilizce) \\
\hline
\end{tabular}

\subsubsection{Yazımı}

Dünya Sağlık Örgütü (DSÖ) tarafından tüm dünyayı etkileyen korona virüsü hastalığının uluslararası camiada covid-19 olarak tanımlanmasından sonra mezkur yazımın yaygınlaşmasının önü açllmıştır. Kaynak dildeki covid-19 şekliyle tüm dünya literatürüne giren bu terimin, Türkçede en azından halk arasında sözcük başında tonsuz şekilde seslendirildiği bilinmektedir. Fakat yazımda hem covid-19 hem de kovid-19 şekillerine aynı mecralarda dahi yer verildiği de görülmektedir. (bkz. Covid-19 Sözlüğü, 2021. Ayrıca bkz. tablo verilerindeki sayısal göstergeler.)

Tablo 13. Kovid-19'un farklı yazımlarının internet arama motorlarındaki sonuçları.

\begin{tabular}{|l|l|l|l|}
\hline \multicolumn{2}{|l|}{ Google } & Yandex & Bing \\
\hline covid & 5.200 .000 .000 & 25.000 .000 & 105.000 .000 \\
\hline covit & 4.450 .000 & 110.000 & 14.000 .000 \\
\hline covid-19 & 6.200 .000 .000 & 10.000 .000 & 79.500 .000 \\
\hline covit-19 & 5.210 .000 .000 & 9.000 .000 & 1.240 .000 .000 \\
\hline kovid & 35.300 .000 & 314.000 & 4.710 .000 \\
\hline kovit & 850.000 & 24.000 & 364.000 \\
\hline kovid-19 & 6.200 .000 .000 & 8.000 .000 & 227.000 \\
\hline kovit-19 & 5.150 .000 .000 & 8.000 .000 & 101.000 \\
\hline
\end{tabular}

Tablo 14. Kovid-19'un farklı yazımlarının sosyal medya platformlarındaki sonuçları.

\begin{tabular}{|l|l|l|}
\hline \multicolumn{2}{|c|}{ Ínstagram } & Facebook \\
\hline covid & 16.500 .000 & 5.400 .000 \\
\hline covit & 134.000 & 25.000 \\
\hline covid-19 & 24.200 .000 & 13.000 .000 \\
\hline covit-19 & 130.000 & 44.000 \\
\hline kovid & 22.900 & 8.200 \\
\hline kovit & 1.000 & - \\
\hline kovid-19 & 107.000 & 18.000 \\
\hline kovit-19 & 5.000 & 1.300 \\
\hline
\end{tabular}

Söyleyişte belli ölçüde kovid-19 sözcüğü Türkçeleştirilse de bu birleştirilmiş terimin en önemli sorunu, yazımıdır. Korona sözcüğüyle ilgili izahat ilgili maddede zaten yapıldı̆̆ı için burada kovid sözcüğünün son sesindeki tonlu harfin varllğı̆yla üzerinde durulacaktır. Tonlulaşma hadisesinin Türkçenin genel bir hususiyeti olmaması (Yelten, 2010: 140), birden fazla heceli kelime tabanlarındaki son sesteki p, ç, t, k, ünsüzlerinin genellikle tonlulaşması (Özkan, 2006: s. 350), kovid şeklindeki söylenişin yazıya aktarılmak istenmesi ve bunun yaygınlaşmış olması (bkz. tablo verilerindeki sayısal göstergeler.), karma yöntemle oluşturulmuş bir birleşik terimin (Coronavirüs Disease 2019) orijinal yazımından daha fazla uzaklaşılmasının arzulanmaması ve yine bu yöntemle oluşturulmuş terimlerin yazımıyla ilgili net bir kuralın var olmaması gibi nedenlerle kovid-19 şeklindeki yazımın tercih edilmesi gerektiği düşünülmektedir.

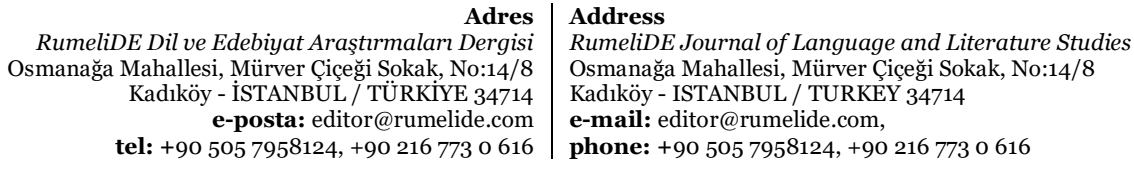




\subsection{Pandemi}

\subsubsection{Tanımı}

Dünya Sağlık Örgütü (DSÖ); Çin’de ortaya çıkan SARS-CoV-2 virüsünün etkisinin başlangıçta sadece bu ülkede olacağını düşünerek önce epidemiyi, sonra da bu virüsün bölgesel olarak kalmadığı ve tüm dünyaya yayıldığını görünce pandemiyi ilan etmiştir.

Tablo 16. Pandeminin tanım bilgileri.

\begin{tabular}{|c|c|}
\hline Covid-19 Sözlü̈̆̆̈̈ (T.C. Sağllk Bakanlığı, 2021) & $\begin{array}{l}\text { Bir hastalığın veya enfeksiyon etkeninin ülkelerde, } \\
\text { kıtalarda, hatta tüm dünya gibi çok geniş bir alanda } \\
\text { yayılım göstermesi. } \\
\text { Açılama: COVID-19, ülkemizde de ilk vakanın } \\
\text { görüldüğ̈ 11 Mart 2020 tarihinde Dünya Sağlı } \\
\text { Örgütü (DSÖ) tarafından pandemi ilan edilmiştir. }\end{array}$ \\
\hline $\begin{array}{l}\text { Latince Trp Terimleri Sözlü̈̆̈̈̈ (Güler, 2012: s. } \\
\text { 294). }\end{array}$ & $\begin{array}{l}\text { Bir hastalığın büyük bir bölge ya da birkaç ülkeyi } \\
\text { etkilediği büyük salgın, pandemi. }\end{array}$ \\
\hline $\begin{array}{l}\text { Rumence Türkçe Sözlük (Mankalyal,, 2013: s. } \\
\text { 668) }\end{array}$ & $\begin{array}{l}\text { Bir ülkede hemen herkesin yakalandığı hastalık, } \\
\text { bulaşıcı bir hastalığın tüm kıtaya yayılması. }\end{array}$ \\
\hline $\begin{array}{l}\text { Hemşirelik Terimleri Sözlü̈̆g̈̈̈ (Hemşire } \\
\text { Terimleri Çalışma Grubu 2015: s. 516) }\end{array}$ & $\begin{array}{l}\text { Bir hastalığın bir kıta ya da birkaç ülke üzerinde aynı } \\
\text { anda yaygın şekilde görülmesi, büyük salgın. }\end{array}$ \\
\hline $\begin{array}{l}\text { Veteriner Hekimliği Sözlüğ } u ̈ \text { (Veteriner } \\
\text { Hekimliği Terimleri Sözlüğü Çalışma Grubu, 2017: s. } \\
\text { 1644) }\end{array}$ & $\begin{array}{l}\text { Coğrafi bir sınırlama olmaksızın belirli bir zaman } \\
\text { periyodundaki enfeksiyonların sayısı. }\end{array}$ \\
\hline
\end{tabular}

Söz konusu tanımlar dikkate alındığında epidemi için salgın, pandemi için de küresel salgın veya büyük salgın karşılıkları önerilebilir. Fakat pandemi yerine küresel salgın sözcügü̈ Türkçede kullanılıp yaygınlaştırabilecekken maalesef pandemi kurulu gibi yeni yapılara müracaat edilmiş, hatta e-devlet üzerinden pandemi sosyal destek başvurusu ekranı açlmıştır. Böylece pandemi resmî adımlarla resmîleştirilmiştir.

\subsubsection{Kökeni}

Dünya Sağlık Örgütü’nün (DSÖ) 11 Mart 2020 tarihinde tüm dünyada kovid-19’u küresel bir hastalık olarak ilan etmesiyle Türkçede de pandemi sözcügüu popüler hâle gelmiştir.

Köken itibarıyla Yunanca olan pandemi, pan+demi sözcüklerinin birleşmesinden oluşmuş bir terimdir. Yunancadan İngilizceye oradan da tüm dünya dillerine geçmiştir.

Tablo 17. Pandeminin köken bilgileri.

\begin{tabular}{|l|l|}
\hline Latince Tip Terimleri Sözlü̆̆̈̈ (Güler, 2012: s. 294) & Yunanca. \\
\hline $\begin{array}{l}\text { Veteriner Hekimleri Sözlüğğü (Veteriner Hekimliği Terimleri Sözlüğü Çalışma } \\
\text { Grubu: 2017, s. 1644) }\end{array}$ & İngilizce. \\
\hline
\end{tabular}

Veteriner Hekimliği Sözlüğ̈̈’nde (Veteriner Hekimliği Terimleri Sözlüğü Çalışma Grubu, 2017: s. 1644) pandeminin köken olarak İngilizceye dayandığı söylense de yukarıdaki diğer terimlerde olduğu gibi burada da taşıyıcı dil olan İngilizcenin referans alındığı anlaşılmaktadır.

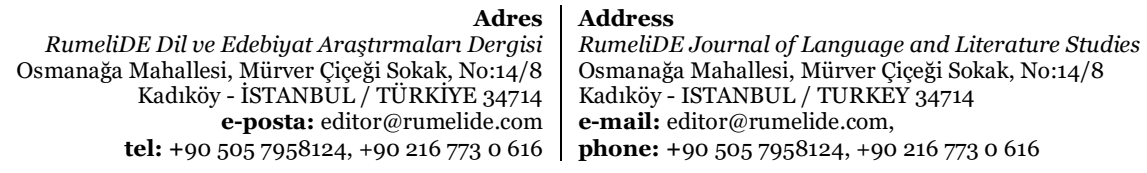




\subsubsection{Yazımı}

Tablo 18. Pandeminin farklı yazımlarının internet arama motorlarındaki sonuçları.

\begin{tabular}{|l|l|l|l|}
\hline \multicolumn{2}{|c|}{ Google } & Yandex & Bing \\
\hline pandemi & 129.000 .000 & 2.000 .000 & 4.710 .000 \\
\hline pandemic & 798.000 .000 & 8.000 .000 & 251.000 .000 \\
\hline pandemik & 138.000 .000 & 38.000 & $38.000^{4}$ \\
\hline
\end{tabular}

Tablo 19. Pandeminin farklı yazımlarının sosyal medya platformlarındaki sonuçları.

\begin{tabular}{|l|l|l|}
\hline \multicolumn{2}{|c|}{ İnstagram } & Facebook \\
\hline pandemi & 527.000 & 106.000 \\
\hline pandemic & 4.200 .000 & 892.000 \\
\hline pandemik & 12.800 & 6.800 \\
\hline
\end{tabular}

Korona, korona virüsü, virüs sözcükleri arasında yazım konusunda en şanslısı pandemidir denilebilir. $\mathrm{Bu}$ alıntı sözcüğün ilk harfinin zaten tonsuz durumda olması, yazımı konusunda en azından sözcük başında pek bir hata yapılmamasını sağlamaktadır. Bu sebeple sözcüğün yazımına pandemi şekliyle devam edilmelidir.

\subsection{Virüs}

\subsubsection{Tanımı}

Virüs, çalışma başlığını oluşturan tüm sözcüklere göre Türkçede daha yerli ve millîdir. En azından Türkçede Artin Hindoğlu'nun (1831: s. 551) kullanmasıyla birlikte iki yüz yıllık bir geçmişi vardır.

Tablo 21. Virüsün tanım bilgileri.

\begin{tabular}{|c|c|}
\hline Covid-19 Sözlü̈̆̆̈̈ (T.C. Sağlık Bakanlığı, 2021) & $\begin{array}{l}\text { Bir genetik materyali bulunan; hücre zarı, çekirdek, } \\
\text { sitoplazma ve organelleri olmayan; yalnızca konak } \\
\text { hücre içinde çoğalabilen, bazıları insanda hastalık } \\
\text { yapan varlı. } \\
\text { Açılama: COVID-19'un etkeni Koronavirüsler } \\
\text { ailesinden SARS-CoV-2 isimli bir virüstür. Virüs } \\
\text { kaynaklı hastalıklara antibiyotikler etki etmez. }\end{array}$ \\
\hline Güncel Türkçe Sözlük (TDK, 2021) & $\begin{array}{l}\text { Hastalık yapıcı, bakterilerden daha küçük, yaşamak } \\
\text { için bir başka hücrenin içine girmek zorunda olan } \\
\text { ancak elektron mikroskobunda görülebilen parazit. }\end{array}$ \\
\hline $\begin{array}{l}\text { Hazine-i Lügat Fransızca-Türkçe Sözlük (Artin } \\
\text { Hindoğlu, 1831: s. 551) }\end{array}$ & Frenk illeti, zehiri. \\
\hline $\begin{array}{l}\text { Latince Türkçe Sözlük (Kabaağaç ve Alova, 1995: } \\
\text { s. 640) }\end{array}$ & $\begin{array}{l}\text { Yapışkan ve nemli herhangi bir madde, yapışkan sıvı; } \\
\text { zehir; iğrenç koku; tuz tadı. }\end{array}$ \\
\hline $\begin{array}{l}\text { Su Ürünleri Terimleri Sözlü̈̆̆̈̈ (Mustafa } \\
\text { Sar1eyyüpoğlu vd, 2009: s. 283) }\end{array}$ & $\begin{array}{l}\text { Ancak elektron mikroskobuyla görülebilen, özel } \\
\text { filtrelerden geçebilen, yalnızca canlı hücreler } \\
\text { içerisinde üreyebilen, RNA veya DNA kitlesinden } \\
\text { oluşmuş, herhangi bir metabolik işlev göstermeyen } \\
\text { mikroorganizma. }\end{array}$ \\
\hline
\end{tabular}

$4 \quad$ Bingde, pandemic için aktarılan sayısal veri, pandemic ile bulunan sonuçla aynıdır.

Adres $\mid$ Address

RumeliDE Dil ve Edebiyat Araştırmaları Dergisi Osmanağa Mahallesi, Mürver Çiçeği Sokak, No:14/8 Kadıköy - ISTANBUL / TÜRKIYE 34714 e-posta: editor@rumelide.com

RumeliDE Journal of Language and Literature Studies Osmanağa Mahallesi, Mürver Çiçeği Sokak, No:14/8

Kadıköy - ISTANBUL / TURKEY 34714 tel: +90 $5057958124,+902167730616$

e-mail: editor@rumelide.com

phone: +90 505 7958124, +90 2167730616 


\begin{tabular}{|c|c|}
\hline $\begin{array}{l}\text { Kimya Terimleri Sözlüğği (Somer ve Yaşar, 2009: } \\
\text { s. 263) }\end{array}$ & $\begin{array}{l}\text { Canlı hücrelerde yaşayan, metabolizmaları } \\
\text { bulunmayan, oksijen kullanılmayan, } \\
\text { makromoleküller oluşturmayan, büyümeyen veya } \\
\text { ölmeyen, fakat sadece canlı hücrelerde üreyen, } \\
\text { biçimleri bakterininkilere benzeyen birçok hastalığa } \\
\text { yol açan, ancak elektron mikroskobunda } \\
\text { belirlenebilecek kadar küçük olan, protein ve nükleik } \\
\text { asitlerden oluşan enfeksiyon yapıcı madde. }\end{array}$ \\
\hline $\begin{array}{l}\text { Türkçe ve Yabance Tip Terimleri Sözlü̈̆̈̈̈ } \\
\text { (Dökmeci ve Dökmeci, 2010: s. 1094) }\end{array}$ & $\begin{array}{l}\text { Zehir. } \\
\text { Ancak canlı organizmalarda asalak çoğalabilen, } \\
\text { bakterilerden çok daha küçük, elektron } \\
\text { mikroskobunda görülebilen ve bir protein tabakasıyla } \\
\text { örtülü, kendine özgü nükleit asit yapı ve sentezi olan } \\
\text { enfeksiyon etkeni canlı. }\end{array}$ \\
\hline $\begin{array}{l}\text { Biyoloji Terimleri Sözlüğ̈̈̈ (Karol vd, 2010: s. } \\
\text { 125) }\end{array}$ & $\begin{array}{l}\text { Bir protein kılıf ve nükleit asit olarak tek ve nükleik } \\
\text { asit olarak tek ya da çift iplikli, düz ya da halkasal } \\
\text { DNA ya da RNA’dan oluşan, inflüenza virüsü gibi } \\
\text { bazı virüslerde nükleik asidi birkaç parçadan } \\
\text { oluşabilen, bazılarında protein kılıfın dışında zardan } \\
\text { oluşan düz ya da üzerinde çıkıntılar bulunan, bir } \\
\text { kılıfları olan, hastalık yapıcı, bakterilerden daha } \\
\text { küçük, yaşamak için bir başka hücrenin içine girmek } \\
\text { zorunda olan ancak elektron mikroskobunda } \\
\text { görülebilen zorunlu parazitler. }\end{array}$ \\
\hline $\begin{array}{l}\text { Latince Tұp Terimleri Sözlü̈̆̆̈̈ (Güler, 2012: s. } \\
466 \text { ) }\end{array}$ & $\begin{array}{l}\text { Zehir; etkili sıvı, ilaçlı sıvı; virüs, büyük bir minicanlı } \\
\text { grubu, 20 ile 250 nanometre arasında büyüklüğe } \\
\text { sahiptir, zorunlu hücre içi asalak canlılardır. Ancak } \\
\text { elektron mikroskobu ile görülebilen virüsler, en az } \\
\text { protein katmanı ile çevrili bir cins nükleit asit içeren } \\
\text { parçacıklar halindedir, girdiği hücrenin nükleit asit } \\
\text { sentez mekanizmasını kendi üremesi için kullanma } \\
\text { özelliğine sahip canlılardır. Bakterilerin geçemediği } \\
\text { süzgeçlerden geçerler. }\end{array}$ \\
\hline $\begin{array}{l}\text { Illaç ve Eczacılık Terimleri Sözlü̈̆g̈̈i (İlaç ve } \\
\text { Eczacılık Terimleri Çalışma Grubu 2015: s. 739) }\end{array}$ & $\begin{array}{l}\text { Bakteri, hayvan ve bitki gibi yalnızca canlı hücreler } \\
\text { içinde yaşayabilen, kendine özgü yapısı ve nükleik asit } \\
\text { genomu olmasına karşın enfekte ettiği hücrelerin } \\
\text { enzimlerini, enerji sistemlerini kullanarak çoğalan ve } \\
\text { ş̧ı mikroskobunda görülemeyen en küçük bulaşıcı } \\
\text { etken. }\end{array}$ \\
\hline $\begin{array}{l}\text { Hemşirelik Terimleri Sözlüğg̈ü (Hemşire } \\
\text { Terimleri Çalışma Grubu, 2015: s. 709) }\end{array}$ & $\begin{array}{l}\text { Genetik materyal olarak DNA veya RNA } \\
\text { nükleotitlerinden birini bulunduran, yaşamak için bir } \\
\text { başka hücrenin içine girmek zorunda olan, } \\
\text { antibiyotiklerin etkilemediği, interferonlara duyarlı, } \\
\text { elektron mikroskobunda görülebilen, bakterilerden } \\
\text { daha küçük, hastalık yapıcı mikrocanl. }\end{array}$ \\
\hline $\begin{array}{l}\text { Veteriner Hekimleri Sözlüğü (Veteriner } \\
\text { Hekimliği Terimleri Sözlüğü Çalışma Grubu, 2017: s. } \\
\text { 2297) }\end{array}$ & $\begin{array}{l}\text { Genetik materyal olarak DNA veya RNA } \\
\text { nükleotitlerinden birini bulunduran, } \\
\text { makromoleküllerinin sentezleyebilmek için kendisine } \\
\text { ait enzim sistemleri bulunmayan ve bu nedenle de } \\
\text { zorunlu hücre içi parazit olan, antibiyotiklerin } \\
\text { etkimediği, interferonlara duyarll, bu gün için } \\
\text { belirlenmiş en küçük mikroorganizma grubu. } \\
\text { Virüs }\end{array}$ \\
\hline Acartürk (2020: s. 357) & $\begin{array}{l}\text { Bakterilerden çok daha küçük, sadece göze içinde } \\
\text { yaşabilen, nükleit asit içeren, hızla bulaşabilen, mini } \\
\text { canlılar. }\end{array}$ \\
\hline
\end{tabular}

Virüsü tek sözcükle karşılamak gerekirse zehir karşılığı verilebilir.

Adres

RumeliDE Dil ve Edebiyat Araştırmaları Dergis Osmanağa Mahallesi, Mürver Çiçeği Sokak, No:14/8 Kadıköy - ISTANBUL / TÜRKIYE 34714 e-posta: editor@rumelide.com tel: +90 $5057958124,+902167730616$
Address

RumeliDE Journal of Language and Literature Studies Osmanağa Mahallesi, Mürver Çiçeği Sokak, No:14/8

Kadıköy - ISTANBUL / TURKEY 34714

e-mail: editor@rumelide.com

phone: +90 5057958124 , +90 2167730616 


\subsubsection{Kökeni}

Tablo 22. Virüsün köken bilgileri.

\begin{tabular}{|c|c|}
\hline Latince Türkçe Sözlük (Kabaağaç ve Alova, 1995: s. 640) & Latince \\
\hline $\begin{array}{l}\text { Türkçe ve Yabance Tip Terimleri Sözlüğ̈̈̈ (Dökmeci ve } \\
\text { Dökmeci, 2010: s. 1094) }\end{array}$ & İngilizce virus, Latince virus. \\
\hline Biyoloji Terimleri Sözlüğ̈̈̈ (Karol vd, 2010: s. 691) & Latince. \\
\hline Latince Tıp Terimleri Sözlü̈̆̈̈̈ (Güler, 2012: s. 466) & Latince. \\
\hline $\begin{array}{l}\text { Su Ürünleri Terimleri Sözlü̈̆̈̈ü (Mustafa Sarıyyüpoğlu vd, } \\
\text { 2009: s. 283) }\end{array}$ & İngilizce. \\
\hline $\begin{array}{l}\text { Veteriner Hekimleri Sözlüğ̈̈ (Veteriner Hekimliği Terimleri } \\
\text { Sözlüğü Çalışma Grubu, 2017: s. 2297) }\end{array}$ & İngilizce. \\
\hline Kimya Terimleri Sözlüğ̈̈̈ (Somer ve Yaşar 2009: s. 263) & Almanca virus, İngilizce virus. \\
\hline
\end{tabular}

Tespit edebildiği kadarıyla virüs sözcüğünü Türkçede ilk kez Artin Hindoğlu (1831: s. 551) FransızcaTürkçe sözlüğünde madde başı olarak vermiştir.

Virüs sözcüğününkökeni Latince olsa da Türkçeye gelişi Fransızca üzerindendir.

\subsubsection{Yazımı}

Latince virus sözcüğü, Türkçedeki ses uyumuna uymuş; her iki hecedeki iki ünlü ön sıradan olacak şekilde sıralanmış ve Türkçede virüs şeklinde yazılagelmiştir. Bu yüzden kaynak dildeki virus yazımı, ikinci hecedeki ünlü dudak uyumuna girmese de kalınlık-incelik uyumuna dâhil edilerek virüs şeklinde yazılmalı ve okunmalıdır.

Tablo 23. Virüsün farklı yazımlarının internet arama motorlarındaki sonuçları.

\begin{tabular}{|l|l|l|l|}
\hline \multicolumn{2}{|c|}{ Google } & Yandex & Bing \\
\hline virus & 1.050 .000 .000 & 13.000 .000 & 67.100 .000 \\
\hline virüs & 44.300 .000 & 3.000 .000 & 1.290 .000 \\
\hline
\end{tabular}

Tablo 24. Virüsün farklı Yazımlarının Sosyal Medya Platformlarındaki Sonuçları.

\begin{tabular}{|l|l|l|}
\hline \multicolumn{2}{|c|}{ Instagram } & Facebook \\
\hline virus & 4.400 .000 & 912.000 \\
\hline virüs & 226.000 & 19.000 \\
\hline
\end{tabular}

\section{Sonuç, tartışma ve öneriler}

Korona, korona virüsü, kovid-19, pandemi ve virüs sözcüklerin tanımı, kökeni ve yazımı konusunda Türkçede iki yıla yakındır hâlâ bir karışıklık ve karmaşıklık yer almaktadır. Söz konusu bu sözcüklerin tanımları, kökenleri ve yazımı ya doğru bilinmemekte/yapılamamakta ya da birbirlerine karıştırılmaktadır.

Korona, korona virüsü ve virüs kelimeleri korona virüsünden önce de Türkçede var olan ve sıklıkla farklı disiplinlerde kullanılan terimlerden olmuştur. Korona virüsünden sonra kovid-19 da terimleşerek Türkçedeki yerini almıştır.

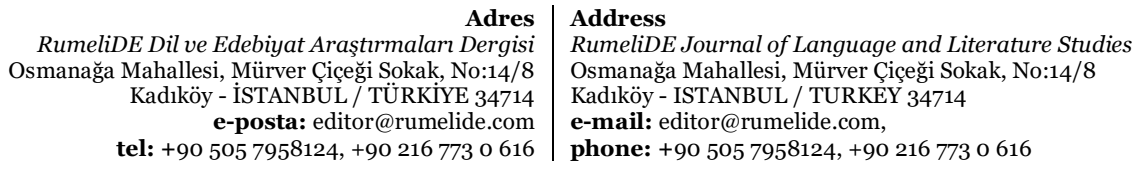


Hastalığa neden olan virüsün mikroskobik incelemesinin taca benzemesi sebebiyle bu virüse korona adı verilmiştir. Benzetmeye dayalı olarak verilen bu yeni anlamın virüs sözcügüyle birleşmesiyle korona virüsü hastalı̆̆ına neden olan virüsün ismi ortaya çlkmıştır. Yani korona virüsü bir hastalık değil hastalığa neden olan virüsün bizatihi ismidir. Dolayısıyla kovid-19 ile korona virüsü hastalığı söylemi anlamca özdeştir ve korona virüsü için yeni tip korona virüsü denilmesi de son derece doğrudur

Korona için taç, korona virüsü için taç virüsü, covid-19 için taç virüsü hastahğı, pandemi için küresel salgin ya da büyük salgın karşılıkları; bu sözcüklerin anlamlarını tek/birden fazla sözcükle karşlamak için verebilir. Artık Türkçeleşmiş olsa da virüs için de zehir tanımı söylenebilir.

Korona, korona virüsü, kovid-19, pandemi, virüs sözcüklerinin basılı ve elektronik kaynaklarda kökenlerine bakıldığı zaman kaynak dil olan Latinceye değil; ağırlıklı olarak taşıyıcı dil durumundaki İngilizceye yer verildiği görülmektedir. Hâlbuki bu sözcüklerden korona ve virüs Latince, pandemi de Yunancadır. Kovid-19 adı da coronavirus disease 2019'un karma yöntemle oluşturulduğu birleşik bir terimdir. "Disease"deki -dis eki Latince ön ektir, "ease" de Fransızcadır. Dolayısıyla kovid-19'unkaynak dilden hareket edilirse - köken olarak Latince-Fransızca sözcüklerin birleştirilmesiyle oluşturulmuş bir birleşik sözcük olduğu söylenebilir. Fakat korona, korana virüs, kovid-19, pandemi ve virüs sözcüklerinin köken, anlam ve yazım olarak taşıуıcısı ve de tüm dünya dillerine bu terimin girmesini sağlayan dil İngilizcedir.

Türkçede sözcük başında birkaç istisna dışında $c$ ünsüzünün bulunmayışı, alıntı sözcüklerin sözcük başında tonsuz hâllerinin yazılışta ve söyleyişte tercih edilmesi sebebiyle korona şeklideki yazım doğrudur ve bu yazım yaygınlaştırılmalıdır.

Yazım Kılavuzu (TDK, 2021) birleşik yazılma hususunu birleşik sözcüklerden ikincisinin anlamını tamamen yitirmesine bağlamıştır. Benzetme yolu düşünülmeden alınan bu karara göre korona virüsü sözcügündeki virüsün anlamında bir değişiklik yoktur. Korona virüsü $\mathrm{ad}+\mathrm{ad}+\mathrm{s}(\mathrm{I})$ yapısıyla terimleştirilmiş belirsiz isim tamlamasıdır ve bu tür belirsiz isim tamlamaları tür adı olmaya da elverişlidir. Ayrıca Türkçede yabancı köklere dayanan sözcükleri yazarken hedef dile göre hareket edilmesi gerekliliği ve belirtisiz isim kategorisindeki sözcükleri ayrı yazmak zaruriyeti sebebiyle korona virüsünün Türkçede ayrı yazılmasını elzem hâle getirmektedir.

Kovid-19, coronavirüs disease 2019 sözcüklerinin harf, hece ve sayllarının karma yöntemle oluşturulduğu bir birleşik terimdir. Orijinalinde covid-19 şeklinde yazılan sözcüğün son sesteki tonlulaşmasının Türkçenin genel bir özelliği olmaması, sözcüğün karma yöntemle oluşturulmuş yeni bir terim olması ve bu şekilde oluşturulmuş terimlerin yazımıyla ilgili kesin bir kuralın mevcudiyetsizliği, halk arasındaki tercihin telaffuzda da olsa tonlu olması, kaynak dilden daha fazla uzaklaşılmasının istenmemesi gibi nedenlerle kovid-19 yazımının tercih edilmesi gerekliliği ortaya çıkmaktadır.

Kaynak dildeki virus yazımı iki yüz yıldır Türkçede olan bu sözcüğü zaten kalınlık-incelik uyumuna sokarak virüs hâline getirmiştir. Tekrardan eskiye dönülmesinin bir gereği yoktur.

Yazım konusu, Batı kökenli sözcüklerin Türkçede son 30-40 yılda yaşadığı daha doğrusu yaşattığı sorunların başında gelmektedir. Korona, korona virüsü, kovid-19, pandemi, virüs gibi sözcüklerin yerli olmaması ve bir anda ortaya çıkarak Türkçeye farklı yapı ve anlamlarla girmesi ve eskisine göre sıklıkla kullanılması başlangıçta çok farklı yazımları da beraberinde getirmiştir. Fakat bu sözcüklerin başlangıçtaki farklı yazımları giderek sayıca azalmış, en azından üçe veyahut ikiye indirilmiştir. Korona

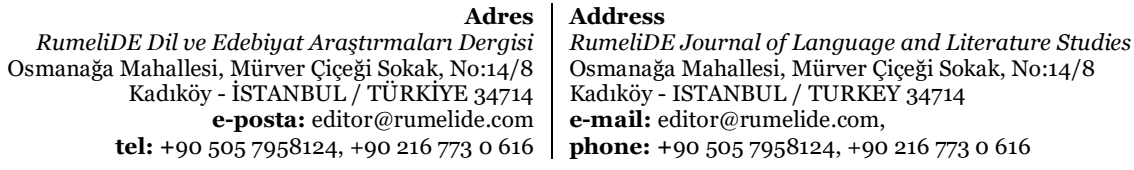


yerine corona; korona virüsü yerine korona virüs, koronavirüs, coronavirus,; kovit-19 yerine covid-19 yazımları zaman zaman bir arada görülse de; Türk halkı bu sözcükleri yaza yaza söyleye söyleye Türkçeleştirecektir. Şu anki mevcut durumun Türk halkının bu sözcüklere duyduğu yabancllık hissinin tam olarak bitmemesinden kaynaklandığı aşikârdır.

Nasıl ki maske-sosyal mesafe-hijyen kurallarına riayet edilerek hayatlara devam ediyorsa Türkçeyi konuşan herkesin de korona, korona virüsü, kovid-19, pandemi, virüs gibi sözcüklerin anlamını ve kökenini doğru bilmesi, yazması ve de okuması gerekmektedir. Bunun için kamu kurum ve kuruluşları başta olmak üzere; yazılı ve görsel basına, sivil toplum kuruluşlarına ve de topyekûn tüm Türk milletine büyük bir sorumluluk düşmektedir.

\section{Türk Dil Kurumunun yapması gerekenler:}

- Güncel Türkçe Sözlük’te korona, korona virüsü, kovid-19, pandemi, virüs sözcüklerinin güncel ve en doğru tanım bilgilerini örnekleriyle birlikte yer vermek.

- Söz konusu terimlerin tanımı ve yazımı konusunda halkı daha yakından bilgilendirmek, bunun için T.C. Sağlık Bakanlığı, yazılı ve görsel basın, sivil toplum kuruluşlarıyla ortak hareket etmek.

- Korona, korona virüsü, kovid-19, pandemi, virüs sözcüklerinin yazımı konusunda daha geniş bir araştırma yaparak bunları kamuoyuyla paylaşmak.

- Ayrı ve bitişik yazılan birleşik kelimelerin yazımıyla ilgili daha kesin ve keskin kurallar belirlemek.

\section{T.C. Sağlık Bakanlığının yapması gerekenler:}

- Covid-19 Bilgilendirme Sayfası içerisinde yer alan Covid-19 Sözlüğ̈̈nde korona, korona virüsü, kovid-19, pandemi, virüs sözcüklerinin tanımlarını sözlük bilimi ilkelerine göre yeniden gözden geçirerek vermek.

- Söz konusu sözcüklerin yazımı konusunda ikilikleri ortadan kaldırıp Türk dilinin kurallarına uygun olan tekli kullanımlara geçmek.

- Covid-19 Sözlüğ̈̈’nde verilen bilgilerin herkesin anlayabileceği bir dilde ve açıklıkta olmasını sağlamak. Bunun için Türk Dil Kurumu ile birlikte hareket etmek.

- Zikredilen terimlerin tanımı ve yazımı konusunda halkı daha yakından bilgilendirmek. Bunu sağlamak için de diğer kamu kurum ve kuruluşlarıyla birlikte hareket etmek.

\section{Yazılı ve görsel basının yapması gerekenler:}

- Korona, korona virüsü, kovid-19, pandemi, virüs sözcüklerinin tanımı, kökeni, yazımı, telaffuzu konusunda daha dikkatli davranmak ve kamuoyunda bilinç oluşmasını sağlamak. Bunun için TDK ve T.C. Sağlık Bakanlığının yönlendirmelerine göre hareket etmek.

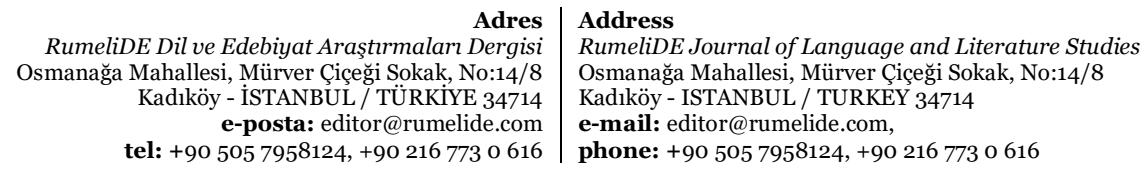

Adres
RumeliDE Dil ve Edebiyat Araştırmaları Dergisi

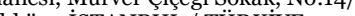
tel: +90 505 7958124, +902167730616 


\section{Sivil toplum kuruluşlarının yapması gerekenler:}

- İ́smi geçen sözcüklerin tanımı, kökeni, yazımı, seslendirilmesi hakkında özellikle sosyal medya aracılığıyla faaliyetlerde bulunmak ve kampanyalar düzenlemek.

- $\quad$ T.C. Sağllk Bakanlığı, TDK başta olmak üzere kamu kurum ve kuruluşlarıyla birlikte bu terimlerle ilgili sosyal sorumluluk projelerini başlatmak ve yürütmek.

\section{Fertlerin yapması gerekenler:}

- Söz konusu kelimelerin anlamı, tanımı, kökeni, yazımı ve telaffuzu konusunda bilinçli olmak ve bunun gerektirdiği şekilde davranmak.

- Zikredilen_terimlerle ilgili düzenlecek sosyal sorumluluk projelerine gönüllü olarak katılmak ve bunlara çevresindekilerin de katılmasını teşvik etmek.

\section{Kisaltmalar}

\begin{tabular}{|l|l|}
\hline bkz. & Bakınız \\
\hline Covid-19 & Coronavirüs Disease 2019 \\
\hline SARS-CoV-2 & Severe Acute Respiratory Syndrome Coronavirus 2 \\
\hline T.C. & Türkiye Cumhuriyeti \\
\hline TDK & Türk Dil Kurumu \\
\hline vb. & ve benzeri \\
\hline
\end{tabular}

\section{Kaynakça}

Acartürk, E. B. (2020). Açıklamah Yürek Bilimi Terimleri Sözlüğü. Ankara: TDK.

Artin Hindoğlu (1831). Dictionnaire Abrégé Français-Turc Hazine-I Lügat. Vienne: F. Beck.

Chambers, W. R. (1874). Chambers's Etymological Dictionary Of The English Language. J. Donald (Ed). London-Edinburg: W\&R Chambers.

Çürük, Y. (2017). Türkçede Birleşik Sözcükler (Isimler). Yayımlanmamış Doktora Tezi. T.C.Ankara Üniversitesi, Sosyal Bilimler Enstitüsü, Ankara.

Derleme sözlüğü (Türkiye Türkçesi Ağızları Sözlüğü) (t.y.). Erişim: 13.02.2021-23.03.2021 tarihlerinde https://sozluk.gov.tr/ adresinden erişilmiştir.

Dökmeci, İ. ve Dökmeci H. (2010). Türkçe ve Yabancı Tpp Terimleri Sözlüğü. (2. Baskı). İstanbul: Nobel Tip Kitapevleri.

Eker, S. (2013). Çağdaş Türk Dili. Ankara: Grafiker Yayınları.

Ergin, M. (2007). Türk Dil Bilgisi. İstanbul: Bayrak Basım.

Güler S. ve Yaşar A. (2009). Kimya Terimleri Sözlüğü. Ankara: TDK.

Güler, Ç. (2012). Latince Tip Terimleri Sözlüğü, Ankara: Palme Yayıncılık.

Hemşirelik Terimleri Çalışma Grubu (2015). Hemşirelik Terimleri Sözlüğü. Ankara: TDK.

İlaç ve Eczacılık Terimleri Çalışma Grubu (2015). İlaç ve Eczacıllk Terimleri Sözlüğü. Ankara: TDK.

İnternet Arama Motoru (Bing). Erişim: 03.04,.2021 tarihinde https://www.bing.com/ adresinden erişilmiştir.

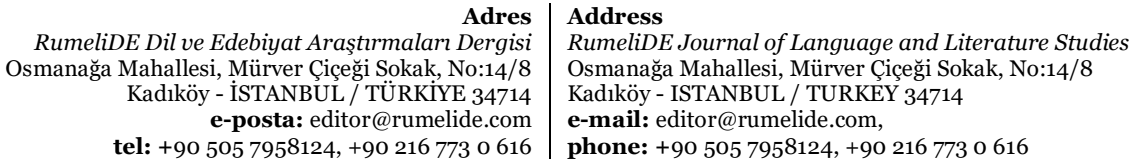


İnternet Arama Motoru (Google). Erişim: 03.04,.2021 tarihinde www.google.com.tr adresinden erişilmiş̧tir.

İnternet Arama Motoru (Yandex). Erişim: 03.04,.2021 tarihinde https://yandex.com.tr/ adresinden erişilmiş̧tir.

Kabaağaç, S. ve Alova, E (1995). Latince Türkçe Sözlük. İstanbul: Sosyal Yayınları.

Karaağaç, G. (2013). Dil Bilim Terimleri Sözlüğü. Ankara: TDK.

Karasar, N. (2009). Bilimsel Araştırma Yöntemi. Ankara: Nobel Yayıncılık.

Karol, S. vd., (2010). Biyoloji Terimleri Sözlüğü. Ankara: TDK.

Kartallığlu, Y. (2015). Söz Kitabı Türkçe-İtalyanca Sözlük. Ankara: TDK.

Korkmaz, Z. (2007a). Gramer Terimleri Sözlüğü. Ankara: TDK.

Korkmaz, Z. (2017b). Türkiye Türkçesi Grameri Şekil Bilgisi. Ankara: TDK.

Mankalyalı, M. Z (2013). Rumence-Türkçe Sözlük. Ankara: TDK.

Özkan, M., Tören, H. ve Esin, O. (2006). Yüksek Öğretimde Türk Dili Yazılı Ve Sözlü Anlatım. (2. Baskı). İstanbul: Filiz Kitabevi.

Parlatır, İ. ve Şahin, H. (2011). Türk Dili Sözlü Ve Yazıl Anlatım Türleri Ile Anlatım Teknikleri. (2. Baskı). Bursa: Ekin.

Paylan, K. (2015). Türkçede Kelime Türetme Yollarına Genel Bir Bakış. Yayımlanmamış Yüksek Lisans Tezi, T.C. Pamukkale Üniversitesi, Eğitim Bilimleri Enstitüsü, Denizli.

Sosyal Medya Platformu (Facebook). Erişim: 05.04.2021 tarihinde https://www.facebook.com/, adresinden erişilmiştir.

Sosyal Medya Platformu (İnstagram). Erişim: 05.04.2021 tarihinde https://www.instagram.com/?hl=tr, adresinde erişilmiştir.

Sağlam, N. vd. (2007). Su Ürünleri Terimleri Sözlüğüu. Ankara: TDK.

Şenel, M. (2009). Kes-Kopyala-Yapıştır; Yeni Kelime Türet. Türk Dili Araştırmaları Yıllı̆̆ı Belleten, 57(2009/1), 99-109.

Şeylan, A. (2014). Üniversiteler için Türkçe Eleştirel Okuma Ve Yazma. (2. Baskı). İstanbul.

Yabancı Sözlere Karşllkklar Kılavuzu. (t.y.) Erişim: 13.02.2021 tarihinde https://sozluk.gov.tr/ adresinden erişilmiştir.

Türk Dili Tetkik Cemiyeti (1934). Osmanlıcadan Türkçeye Söz Karşllkları Tarama Dergisi. (cilt 1). Ankara: TDTC.

Türk Dil Kurumu (t.y.). Yazım kılavuzu. Erişim: 13.03.2021 tarihinde https://www.tdk.gov.tr/kategori/icerik/yazim-kurallari/ adresinden erişilmiştir.

Türk Dil Kurumu (t.y.). Erişim: 13.02.2021 tarihinde https://sozluk.gov.tr/ adresinden erişilmiştir.

Üstünova, M., Aydın H., Berberoğlu, G., Üstünova, K., Akkök, M., Akgün, N. (2009). İş Yeri Adlarında

Türkçenin Kullanımı. Turkish Studies-International 190 Periodical For the Languages, Literature and History of Turkish or Turkic, 4(8), 395-411.

Veteriner Hekimliği Terimleri Sözlüğü Çalışma Grubu (2017). Veteriner Hekimliği Terimleri Sözlüğüu. Ankara: TDK.

Yelten, M. (2010) Fakülteler ve Yüksekokullar Için Türk Dili Ve Anlatım Bilgileri. İstanbul: Doğu Kütüphanesi.

Zülfikar, H. (1991a). Terim Sorunları ve Terim Yapma Yolları. Ankara: TDK.

Zülfikar, H. (2015b). Söz Varlı̆̆ı, Yazım ve Anlatım Açısından Türkçedeki Gelişmeler. Ankara: TDK.

Zülfikar, H. (2020c). Gündemi Meşgul Eden Sağlık Terimleri. Türk Dili Dergisi, 69(821), 10-16.

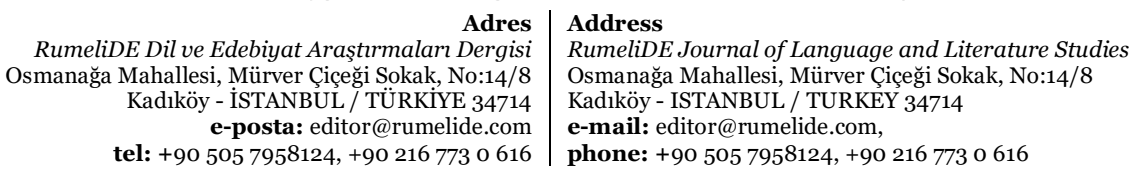

